\title{
Study to Initiate Mobile Learning among a Group of Young Farmers from Kandy District: An Activity Theory Based Approach
}

\author{
U. Dissanayeke*, K.P. Hewagamage ${ }^{1}$, Robert Ramberg ${ }^{2}$, Gihan Wikramanayake ${ }^{1}$ \\ Department of Agricultural Extension \\ Faculty of Agriculture, University of Peradeniya \\ Sri Lanka
}

\begin{abstract}
Mobile phones have been successfully used in agriculture information dissemination. However, there was little emphasis on how to use them in facilitating learning. This study was conducted to define the learning context, with an aim to initiate mobile learning research, in agriculture informal learning. Objectives of the study were to i) define the mobile learning context in relation to Activity Theory principles, ii) describe the present methods of communications and interactions among the study community, and iii) explore the limitations in the traditional non-formal learning context and possible solutions. A design based research methodology, which is informed by Activity Theory principles, was adopted to define the learning context. Members of the Young Farmer Club (YFC), Ankumbura were selected for the study, while data were collected using quantitative and qualitative methods. The availability of mobile phones was quite high (76\%) among the study group, while mobile based interactions were commonly used in accessing agriculture related information. Present methods of interactions and communications among the study group were found to be inefficient, costly and time consuming. Thus, they preferred an efficient, low cost, and simple method to replace the existing systems. They further needed a mobile based learning system to help gain knowledge on general agricultural practices. Future research is necessary to develop a suitable communication and interaction system and a mobile learning system.
\end{abstract}

Keywords: Activity theory, ICT in agriculture education, mobile learning, Young Farmer Clubs

\section{INTRODUCTION}

Mobile phones are becoming increasingly popular in the contemporary world. A recent study conducted in the North Central Province of Sri Lanka, suggests more than $70 \%$ of the farmers possess mobile phones (Dissanayeke and Wanigasundera, 2014). The country also has some of the lowest mobile-cellular prices in the world when compared to the other countries with much higher GNI - Gross National Income per capita levels (ITU, 2012). Besides the literacy levels among the population is also quite high. Consequently, mobile phones have been successfully used in agriculture information dissemination in the Sri Lankan context. However the emphasis on using mobile phones to facilitate learning was limited. Even though most of the mobile phones are not originally designed as learning devices, they possess necessary qualities and functionalities that can be used in facilitating

University of Colombo School of Computing, University of Colombo, Sri Lanka Department of Computers and Systems Sciences, Stockholm University, Sweden Corresponding author: uvasarad@gmail.com 
learning, such as representing, communicating, and interacting. As a result, mobile phones are quite often used in fostering learning, in both formal and informal contexts.

This study was conducted to define the m-Learning context for agricultural informal learning. The objectives of the study were to; i) define the m-Learning context referring to Activity Theory concepts, ii) explore the present communication and interactions process among the study community, and iii) study the limitations in the traditional non-formal learning context and possible solutions.

Activity Theory was used as an inspiration and guiding principle to define, analyze, and interpret the learning context. A design based research approach was followed, so that the researchers and practitioners can work collaboratively throughout the research process. The findings of the study will be used as a basis to initiate m-Learning with the study community in future.

\section{M-learning}

Definitions for m-Learning are mostly constructed on four important concepts; pedagogy, technical devices, context of learning, and social interactions. Following these concepts mLearning is simply defined as 'learning across multiple contexts, through social and content interactions, using personal electronic devices' (Crompton, 2013).

Earlier attempts in defining m-Learning have been made mostly in relation to e-Learning while m-Learning was merely considered as an extension to e-Learning. Later the emphasis was changed to mobile devices, while the concept of mobility was explained in relation to learner mobility, offered by the device, as and when the learner move from one location to another. For example O'Malley et al. (2003) defined m-Learning as 'any sort of learning that happens when the learner is not at a fixed, predetermined location, or learning that happens when the learner takes advantage of the learning opportunities offered by mobile technologies'.

The success of an m-Learning project can be affected by many factors. For an example ownership, and access to technology (Naismith and Corlett, 2006; Reynolds et al., 2010) are two significant factors that influence user acceptance and adoption of an m-Learning project. These qualities can be incorporated in the m-Learning design either by developing the $\mathrm{m}$ Learning system to match with users' own devices or by providing the learners with devices which they may use when needed. These considerations would further help the users to overcome technical problems due to unfamiliarity of the device by reducing the cognitive load needed to study the user interface' (Reynolds et al., 2010). Integration, connectivity, and institutional support (Naismith and Corlett, 2006) are the other important factors which contribute for successful m-Learning implementations. M-learning projects that are integrated with real life situations have a better chance of being successful, while it is also important to ensure connectivity so that learners can access learning material easily from anywhere.

Liaw et al. (2010) conducted an user-experience analysis with 152 participants and reported that 'enhancing learners' satisfaction, encouraging learners' autonomy, empowering system functions, enriching interaction and communication activities have significant positive influences on the acceptance of m-Learning systems'. 


\section{Activity theory}

Activity Theory (AT) is a conceptual approach which provides a broad framework to describe the structure, development and context of learning activities (Nardi, 1995). It is also considered as a powerful analytical tool to study major dimensions of m-learning. Activity Theory as conceptualized by Engestrom (1987) provides the basis for this study. Fig. 1 shows the basic structure of a learning activity.

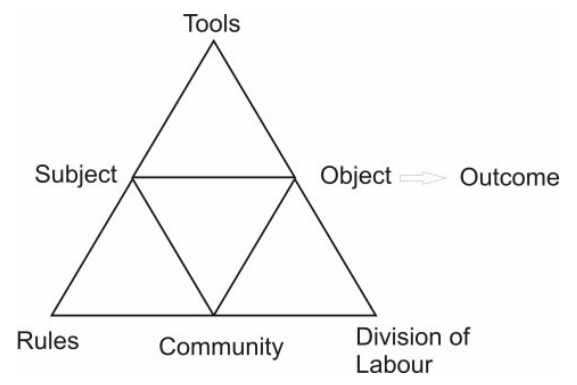

Fig. 1. Basic structure of a learning activity (Source: Engeström, 1987)

According to AT, learning is regarded as an activity, performed by a subject (learner) to achieve a certain object or goal (Fig. 1). The subject can be an individual farmer, while her object would be to acquire knowledge on agriculture best practices. The relationship between the subject and object is mediated by tools or artifacts, which include material tools as well as tools for thinking (Kuutti, 1995). In this research, a mobile phone is regarded as a tool to mediate the relationship between farmer and his goal to acquire knowledge. The surrounding community supports the subject to achieve object by performing various roles such as instructors, peers and education institutions (Fig. 1). Thus the object necessarily has to be sharable among the subject and community so that it can be used in the manipulation and transformation process (Kuutti, 1995). The relationship between the subject and community is mediated by rules which are understood and agreed upon by both parties. The object eventually transforms to an outcome, e.g. getting a better harvest, which motivates further existence of the activity.

\section{Mobile phones in agriculture information dissemination}

Mobile phones had been successfully used to disseminate agriculture information in the resent years (Aker, 2010; Fafchamps and Minten, 2012; Islam and Alawadhi, 2008). The types of information delivered were mostly related to market information, weather information, and crop advice while most of these attempts were limited to Short Message Service (SMS) based approaches. These information dissemination systems can be regarded as closed, and one-way systems in which, information were passed down to the farmers who were already registered with the system. There are two such mobile based information dissemination systems presently functioning in Sri Lanka; Dialog tradenet platform, which collaborates with Govi Gnana Seva project to provide market information from the dedicated economic centres (de Soyza, 2014; Dialog Axiata PLC, 2012), and Hector Kobbekaduwa Agrarian Research and Training Institute (HARTI) collaborated with Mobitel Pvt Ltd. to distribute market price information to interested parties (HARTI, 2014). 
Apart from the above market information systems, the use of mobile phones in facilitating learning is somewhat rare. In fact a meta-analysis, which covers m-Learning research from 2003-10, suggests that mobile learning research are extremely rare in the field of agriculture (Wu et al., 2012). Hansen and Hansen, (2009) studied potentials for mobile learning with a group of Danish farmers and reported some of the barriers in delivering learning objects to farmers through mobile phones. These farmers have not been using a given m-Learning system, mainly due to factors such as demands for downloading, installing, and synchronizing or similar technical manoeuvres.

Wijeratne and Silva (2013) recently reported using an interactive voice response (IVR) system to deliver information among a group of mushroom farmers. These lessons are developed as two minutes long voice-clips and more than 5000 clients have listened to these lessons.

\section{Design based research}

Design based research can be defined as a "systematic but flexible methodology aimed to improve educational practices through iterative analysis, design, development, and implementation, based on collaboration among researchers and practitioners in real-world settings, and leading to contextually-sensitive design principles and theories" (Wang and Hannafin, 2005). The term 'design based research' covers an array of research methods that includes design experiments, design research, development research, developmental research, and formative research.

\section{METHODS}

In this study, a design based research methodology, informed by activity theory principle, was adopted to define the learning context. This was necessary to get the active involvement of the users in the design process and also to have a sense of ownership of the m-Learning system from the beginning. The study was planned to be conducted in 4 phases namely defining the learning context and problems, designing a learning solution, iterative testing and development of solution, and evaluation. This paper covers only the first phase i.e. defining the learning context and problems.

\section{Study community}

Young Farmers Club (YFC), Ankumbura located in the Kandy district was purposively selected for the study. The selection of this particular farmer group was based on the recommendations of the YFC headquarters considering their involvement in agriculture based activities during the last three years. YFCs are usually convened by an Agriculture Instructor (AI) who also acts as the non-formal educator for the farmers.

\section{Data collection}

Primary data were collected using both quantitative and qualitative methods. A questionnaire was used to understand the learner characteristics, and perceived problems in the traditional non-formal learning context. Twenty five respondents out of 44 YFC members participated in the questionnaire survey. Five follow-up interviews were conducted with selected respondents to obtain further information. Two key informant discussions were held with the 
$\mathrm{AI}$ and an officer in charge of YFCs to see the possible problems in the learning context. One focus group discussion held at the AI's office to discuss the problems and possible solutions for the present system of interaction and communication. Five YFC members and the AI participated in the focus group. Secondary information was collected from reports available in the AI's office. Activity Theory was used as an analytical framework in preparation of the data collection instruments. The study community was pre-informed of the research process, and to the fact that the discussions and interactions would be leading to develop a mobile based learning solution to complement the present system of non-formal learning.

\section{Data analysis}

Quantitative data from the questionnaires were analysed using descriptive methods such as frequency analysis using the Statistical Package for Social Sciences (SPSS). Qualitative data was analysed and interpreted referring to AT framework in order to understand and describe the learning context. Results coming from both quantitative analysis and qualitative analysis were interpreted in relation to Activity Theory concepts.

\section{RESULTS AND DISCUSSION}

\section{Learning context analysis}

The learning context was analyzed in relation to the main concepts of the AT; subject, tools, object, community, rules, and division of labour (Fig. 2) while giving more emphasis on the first two elements i.e. subject and tools. This was necessary to identify the learner requirements for a mobile based learning solution.

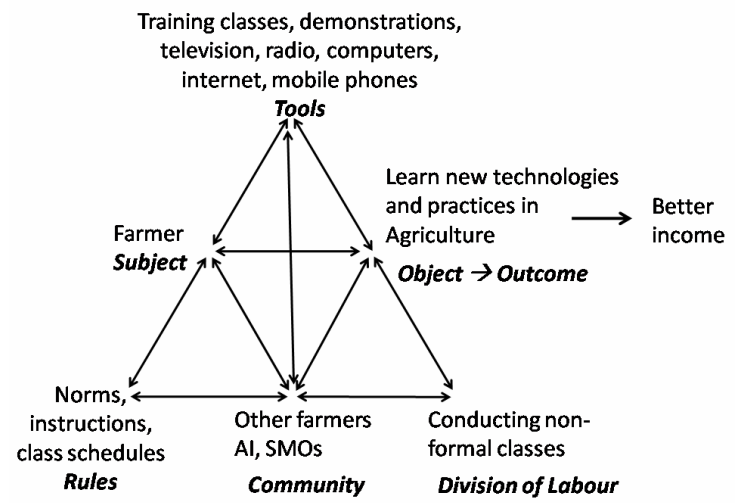

\section{Fig. 2. Agriculture learning context analysis based on the Activity Theory concepts}

An individual farmer was regarded as the subject whose objective is to learn the latest technologies and practices in agriculture. This would lead them to have a better knowledge regarding farming which eventually leads for a better income. The knowledge acquisition process is mediated by tools such as training programmes, demonstrations, learning contents, mobile phones, and computers. The community included the AI, other YFC members, other farmers, and subject matter officers (SMOs). The community divided their labour in terms of conducting training programmes, sharing information related to new practices etc. in order to 
support the subject in reaching her object. The interactions between the subject and community was controlled and mediated by formal and informal rules to which both parties adhere to. For example YFC members adhered to the code of conduct which is a formal document. There were also informal agreements between members regarding participation in non-formal discussion classes, and informing others on training opportunities.

'An activity is regarded as a systemic whole in which each element has a relationship to every other element in the system' (Kuutti, 1995). These intra-relationships, indicated in the Fig. 2 played an important role when studying the learning context. For example, the farmers (subject) used mobile phones (tools) to communicate with the AI (community), so as to learn about the non-formal class schedule (Rule).

\section{Subject analysis}

The study community consists of young farmers who were involved in at least one agriculture production activity. There were several school going members in the group who have either their own agri-based activities or who were supporting the family business during after school hours. This is a common practice in rural areas where children help the family farm during their leisure time. Farmer's characteristics were studied mainly to determine their ability and willingness to participate in an m-Learning project (Table 1).

Table 1. Analyzing characteristics of the subject (learner)

\begin{tabular}{|c|c|c|c|c|}
\hline \multirow{2}{*}{ Characteristics } & \multirow{2}{*}{\multicolumn{2}{|c|}{ Measurements }} & \multicolumn{2}{|c|}{ Number of respondents $=25$} \\
\hline & & & Number & Percentage \\
\hline \multirow[t]{2}{*}{ Age } & \multirow[t]{2}{*}{ Years } & $14-19$ & 7 & $28 \%$ \\
\hline & & $20-35$ & 18 & $72 \%$ \\
\hline \multirow[t]{3}{*}{ Education level } & \multirow{3}{*}{$\begin{array}{l}\text { Years } \\
\text { attended } \\
\text { formal } \\
\text { education }\end{array}$} & $\begin{array}{l}\text { 9-11 years (Up to } \\
\text { O/L) }\end{array}$ & 8 & $33 \%$ \\
\hline & & 13 years $(\mathrm{A} / \mathrm{L})$ & 10 & $42 \%$ \\
\hline & & 16 years (Degree ) & 6 & $25 \%$ \\
\hline \multirow[t]{2}{*}{ Gender } & \multirow{2}{*}{$\begin{array}{l}\text { Male / } \\
\text { female }\end{array}$} & Male & 8 & $32 \%$ \\
\hline & & Female & 17 & $68 \%$ \\
\hline \multirow{2}{*}{$\begin{array}{l}\text { Agriculture as a } \\
\text { subject for } \mathrm{O} / \mathrm{L}\end{array}$} & \multirow[t]{2}{*}{ Yes / no } & Yes & 9 & $36 \%$ \\
\hline & & No & 16 & $64 \%$ \\
\hline \multirow{2}{*}{$\begin{array}{l}\text { Access to a } \\
\text { mobile phone }\end{array}$} & \multirow[t]{2}{*}{ Yes/no } & Yes & 19 & $76 \%$ \\
\hline & & No & 6 & $24 \%$ \\
\hline \multirow{4}{*}{$\begin{array}{l}\text { Mobile phone - } \\
\text { model }\end{array}$} & & Smart phone & 1 & $4 \%$ \\
\hline & & Java enabled phone & 6 & $26 \%$ \\
\hline & & Basic feature phone & 12 & $52 \%$ \\
\hline & & Don't know & 4 & $18 \%$ \\
\hline
\end{tabular}

Results revealed that the majority of the study group were between 20-35 years of age (72\%) and were females (68\%). About $36 \%$ of the respondents have studied agriculture for GCE 
O/Ls. Almost all of them were well experienced with the formal system of education, which is regarded as a positive factor when planning for an m-Learning system.

Table 1. Analyzing characteristics of the subject (learner) contd.

\begin{tabular}{|c|c|c|c|c|}
\hline \multirow[t]{2}{*}{ Characteristics } & \multirow{2}{*}{\multicolumn{2}{|c|}{ Measurements }} & \multicolumn{2}{|c|}{$\begin{array}{c}\text { Total number of respondents }= \\
25\end{array}$} \\
\hline & & & Number & Percentage \\
\hline \multirow{4}{*}{$\begin{array}{l}\text { Access to a } \\
\text { computer with } \\
\text { internet facility }\end{array}$} & & Yes, in my home & 10 & $40 \%$ \\
\hline & & $\begin{array}{l}\text { Yes, in a friend's } \\
\text { place }\end{array}$ & 6 & $24 \%$ \\
\hline & & $\begin{array}{l}\text { Yes, a public } \\
\text { facility }\end{array}$ & 1 & $4 \%$ \\
\hline & & No access & 8 & $32 \%$ \\
\hline \multirow{16}{*}{$\begin{array}{l}\text { Familiarity with } \\
\text { the features of } \\
\text { mobile phones }\end{array}$} & \multirow{4}{*}{$\begin{array}{l}\text { Frequency } \\
\text { of using } \\
\text { Calls }\end{array}$} & Often & 12 & $54.5 \%$ \\
\hline & & Sometimes & 9 & $41 \%$ \\
\hline & & Never & 1 & $4.5 \%$ \\
\hline & & $\begin{array}{l}\text { Facility not } \\
\text { available }\end{array}$ & - & - \\
\hline & \multirow{4}{*}{$\begin{array}{l}\text { Frequency } \\
\text { of using } \\
\text { SMSs }\end{array}$} & Often & 10 & $40 \%$ \\
\hline & & Sometimes & 10 & $40 \%$ \\
\hline & & Never & 2 & $8 \%$ \\
\hline & & $\begin{array}{l}\text { Facility not } \\
\text { available }\end{array}$ & - & - \\
\hline & \multirow{4}{*}{$\begin{array}{l}\text { Frequency } \\
\text { of using } \\
\text { Camera }\end{array}$} & Often & - & - \\
\hline & & Sometimes & 9 & $47.4 \%$ \\
\hline & & Never & 4 & $21.1 \%$ \\
\hline & & $\begin{array}{l}\text { Facility not } \\
\text { available }\end{array}$ & 6 & $31.6 \%$ \\
\hline & \multirow{4}{*}{$\begin{array}{l}\text { Frequency } \\
\text { of using } \\
\text { the } \\
\text { Internet }\end{array}$} & Often & 1 & $6.7 \%$ \\
\hline & & Sometimes & 3 & $20 \%$ \\
\hline & & Never & 4 & $26.7 \%$ \\
\hline & & $\begin{array}{l}\text { Facility not } \\
\text { available }\end{array}$ & 7 & $46.7 \%$ \\
\hline \multirow{5}{*}{$\begin{array}{l}\text { Exposure to } \\
\text { computer based } \\
\text { learning in the } \\
\text { past } \\
\text { Affordability of } \\
\text { m-Learning }\end{array}$} & \multirow{2}{*}{$\begin{array}{l}\text { Use of } \\
\text { IMM CDs }\end{array}$} & Yes & 11 & $44 \%$ \\
\hline & & No & 14 & $56 \%$ \\
\hline & \multirow{3}{*}{$\begin{array}{l}\text { Monthly } \\
\text { expenses } \\
\text { on phone } \\
\text { (Rs.) }\end{array}$} & $<$ LKR 300 & 7 & $33.3 \%$ \\
\hline & & $300-800$ & 13 & $62 \%$ \\
\hline & & > LKR 800 & 1 & $4.7 \%$ \\
\hline
\end{tabular}


The majority had access to a mobile phone (76\%) and a computer with the Internet facility $(68 \%)$. Accessibility and use of various features of mobile phones, is considered necessary because this knowledge would be necessary when designing for an m-Learning system. Most commonly used features of the mobile phone were making calls $(95 \%)$ and text messages $(80 \%)$ while accessing the Internet $(26 \%)$ is quite low. The majority $(52 \%)$ had basic feature phones while only a few had access to a java enabled phone $(26 \%)$ or smart phone $(4 \%)$. This could be one possible reason for the less use of Internet using the mobile phone, as majority did not have access to smart phones. About $62 \%$ of the farmers said they spent Rs.300-800 per month for their mobile phone.

When initiating a system of m-Learning with a novice community, it needs extra motivation to assure sustainability of the m-Learning system (Zuga, et al., 2006). The two characteristics of the subject studied in relation to motivation were their business interests and attitudes (Table 2). When the information provided by an m-Learning system is directly related to the business interests of the subject, the user is more likely to be committed for the m-Learning system. This is because 'relevance' of study material is one of the important principles of non-formal education, which assures user commitment. The majority of the farmers were interested in home gardening $(76 \%)$, while the rest were interested in floriculture business (40-68\%) and mushroom cultivation (24\%). This gives a clear picture of the interests of the study community and possible learning content to be developed when designing $\mathrm{m}$-Learning interventions. The majority $(91.7 \%)$ had favourable attitudes towards a mobile based learning solution.

Table 2. Business interests and attitudes of the subjects (learners)

\begin{tabular}{|c|c|c|c|c|}
\hline \multirow{2}{*}{$\begin{array}{l}\text { Characteristi } \\
\text { cs }\end{array}$} & \multirow{2}{*}{\multicolumn{2}{|c|}{ Measurements }} & \multicolumn{2}{|c|}{$\begin{array}{c}\text { Total number of respondents } \\
=25\end{array}$} \\
\hline & & & Number & Percentage \\
\hline \multirow{5}{*}{$\begin{array}{l}\text { Business } \\
\text { interests (Type } \\
\text { of information } \\
\text { preferred) }\end{array}$} & \multirow{5}{*}{$\begin{array}{l}\text { Type of } \\
\text { cultivation - } \\
\text { Nominal }\end{array}$} & Anthurium cultivation & 17 & $68 \%$ \\
\hline & & Orchid cultivation & 10 & $40 \%$ \\
\hline & & Home gardening & 19 & $76 \%$ \\
\hline & & Mushroom cultivation & 6 & $24 \%$ \\
\hline & & $\begin{array}{l}\text { Cut foliages,pot } \\
\text { plants }\end{array}$ & 14 & $56 \%$ \\
\hline \multirow{3}{*}{$\begin{array}{l}\text { Attitudes } \\
\text { towards m- } \\
\text { Learning }\end{array}$} & \multirow{3}{*}{$\begin{array}{l}\text { Scale 1-3: } \\
1= \\
\text { favourable, } \\
3=\text { poor }\end{array}$} & Favourable & 22 & $91.7 \%$ \\
\hline & & Moderate & 2 & $8.3 \%$ \\
\hline & & Poor & - & - \\
\hline
\end{tabular}

\section{Tools}

According to the Activity Theory, tools refer to the artifacts that mediate the interaction between subject and object. Tools can be materials, methods, ideas, or even procedures (Uden et al., 2008). The study community used a variety of tools to improve their knowledge such as mobile phones and associated features e.g., calls, SMSs, non-formal classes etc. as presented in Table 3 . 
Table 3. Tools used among the study community

\begin{tabular}{|c|c|}
\hline Category & Tools \\
\hline $\begin{array}{l}\text { Individual } \\
\text { level }\end{array}$ & $\begin{array}{l}\text { Mobile phones and features of the mobile phones e.g. calls, Short } \\
\text { Message Service (SMS) } \\
\text { Computers, internet }\end{array}$ \\
\hline Group level & Non-formal classes/ Discussions, Training programmes/ demonstrations \\
\hline Mass level & $\begin{array}{l}\text { Radio quiz programme, Television programmes } \\
\text { News papers and other publications e.g. books, magazines, brochures, } \\
\text { leaflets, posters } \\
\text { Websites, computer based learning resources }\end{array}$ \\
\hline
\end{tabular}

\section{Mobile based communications and interactions}

Studying the present level of mobile based communications and interactions among the study community was regarded as one of the main interests of this study (Fig. 3). This was considered as important when designing an m-Learning interventions.

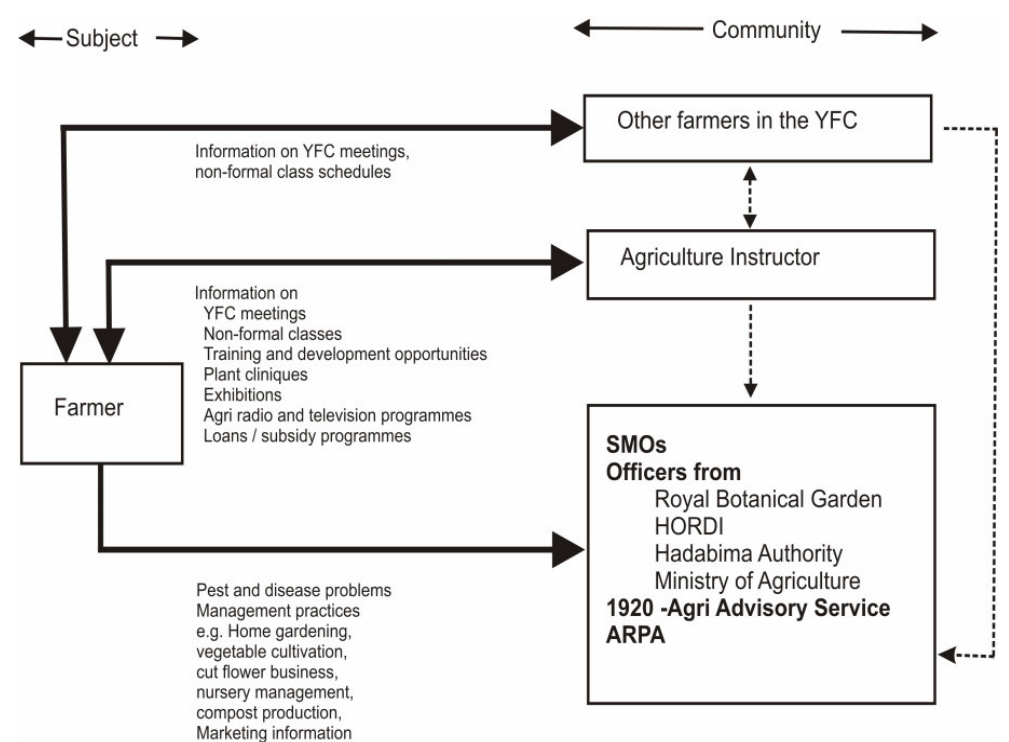

Fig. 3. Present system of mobile based communications and interactions

More than $75 \%$ of the YFC members owned mobile phones and they used their phone to communicate with the community to exchange information related to agriculture, YFC activities, non formal class schedules etc. A mobile phone has made it much easier and cost effective method when compared to the time and money they may have to spend on travelling and personally meeting the community to obtain such information. It was observed that often the farmer initiated the communication process, by making a call or sending a text message to the community. These calls were made for various reasons e.g., to obtain 
technical information related to pest and disease problems, to learn marketing opportunities, subsidies and other incentives for YFC members etc. The community is represented by other farmers in the YFC, officers from the Department of Agriculture and other agriculture related institutions. The farmers have established contacts with these officers when they visited the research organizations, or when they have taken part in training programmes arranged by these officers.

Interactions between the subject and other farmers in the area were mostly two-way interactions. They usually call or text the other farmers to learn about meetings and non formal classes. The AI also initiated a number of communications and interactions when he made calls or sent SMSs to the farmers to inform them of non-formal classes and other learning opportunities.

\section{Problems and limitations in the present learning context}

Problems and limitations in the present learning context were investigated through follow-up discussions with selected farmers, and the AI. The scope of the tools was further limited to mobile phones and their features that are presently used among the study community.

One of the main problems, as viewed by the community, was the inefficiency of scheduling non-formal classes or other YFC events. This was due to the fact that the AI had to make repeated calls and/or send a number of text messages to each and every member in the farmer group. The farmers are scattered, isolated and they take part in the non-formal classes mostly when they think it is relevant and interesting for them. They were pre-occupied with a number of other activities, including managing the farm business, thus non-formal classes were obviously not their first priority of the day. They opt to participate in these classes when it is not clashing with their day-to-day work. In this context, the AI had to make extra efforts to get in touch with the farmer group when scheduling any meetings, and confirmation of meetings. The AI had to call them individually or the subject had to call the AI or other farmers to learn the schedule. The AI explained the situation saying 'the present mobile based communication and interaction methods are inefficient, costly and time consuming'. According to him, the number of non-formal classes that could have been conducted in the study group had been reduced due to this reason. Only a fewer number of farmers participating in a training class (i.e. 5-8 farmers per session) was also noted. This limits the opportunities for the subject to be effectively presented through a non-formal education system.

The study group is also planning to attend a radio quiz programme, which is held among the YFCs at national level, conducted by the Farm Broadcasting Service. The study community considers it as a need to improve their knowledge related to general agriculture practices to win this competition. The present method of teaching-learning process for the quiz programme was through a series of face-to-face discussions. The study community finds this method as time consuming, costly, and interfering with their daily schedules, as they have to visit the AI office regularly to take part in these discussions.

\section{Possible mobile based solutions}

Possible solutions for the above problems were discussed in a focus group to explore the possible solutions. Two such solutions were identified. Firstly, they needed to replace the present system of communication and interactions with an easy to operate, and low cost 
technology. A mobile based network to link subject with community was identified in this regard.

Secondly, the study community preferred a technology enhanced learning system in the place of the present teaching-learning system for the agricultural quiz programme. When compared to an online system or a computer based system, the majority was willing to go for an mobile based system due to two reasons; availability and familiarity with mobile phones were quite higher within the study group, and it is easy to use a mobile based system at any time and from any place, even while travelling. They were particularly in favour of a SMS based method as the majority had basic feature phones. They further suggested a system which can be used when they are free and that does not interfere with their day-to-day work schedules. One of the YFC members commented that "We need a low cost, easy to operate, mobile technology based system to learn new technologies related to agriculture and environment management". Some of them even see it as worthwhile to bear the cost for SMSs as one of them commented "We prefer a mobile technology based information system to learn new practices in agriculture. Even though this will cost us some money, given the benefits of saving time and efforts of travelling, it is worthwhile"

\section{CONCLUSIONS AND FUTURE IMPLEMENTATIONS}

Mobile phone availability, familiarity and affordability were quite satisfactory among the study community thus there is a good opportunity to facilitate mobile based methods of learning and information sharing. The study group members were also young, have a good exposure with curriculum based formal learning systems, and have positive attitudes.

Problems that need to be addressed though a mobile based learning solution were identified as the main outcome of the research. First, the study community is in need of a low cost, efficient, and easy to operate system to facilitate their present system of communication and interactions. Secondly they need a mobile based learning mechanism to enhance their knowledge related to general agriculture practices.

Future research is necessary to develop suitable communication and interaction systems and mobile learning mechanisms for the study community to address the requirements studied above. It is important to design such systems in collaboration with the practitioners in order to assure easy adoption and sustenance.

\section{ACKNOWLEDGEMENT}

The authors wish to acknowledge:

1. Human Resource Development component of the HETC project for funding this project

2. Mr. Manjula Wijesinghe and the members of Young Farmer Club Ankumbura, for taking part in the research process from 2012-2014. 


\section{REFERENCES}

Aker, J.C. (2010). Information from markets near and far: Mobile phones and agricultural markets in Niger. American Economic Journal: Applied Economics. 2, 46 - 59.

Crompton, H. (2013). A historical overview of m-learning: Toward learner-centered education. pp. 3-14. In: Muilenburg, Z.L. and Berge, L.Y. (Ed.) Handbook of Mobile Learning. Routledge, Florence, KY.

De Soyza, M. (2014). Dialog Tradenet. [online]. [Accessed on 04.05.2014]. Available at http://digitalknowledgecentre.in/listings/dialog-tradenet/

Dialog Axiata PLC. (2009). Dialog Tradenet - GGS Partnership set to Revolutionise Agri Market Access [online]. [Accessed on 04.05.2014]. Available at http://www.dialog.lk/news/dialog-tradenet-ggs-partnership-set-to-revolutionise-agri-marketaccess/

Dissanayeke, U. and Wanigasundera, W.A.D.P. (2014). Mobile based information communication interactions among major agriculture stakeholders : Sri Lankan experience. Electronic Journal of Information Systems in Developing Countries. 60, 1 - 12.

Engeström, Y. (1987). Learning by Expanding: An Activity Theoritical Approach to Developmental Research. Orienta-Konsultit Oy, Helsinki, Finland.

Fafchamps, M. and Minten, B. (2012). Impact of SMS-based agricultural information on Indian farmers. The World Bank Economic Review. 26(3), 383 - 414.

Hansen, J.P. and Hansen, N.F. (2009). M-learning in agriculture :Ppossibilities and barriers. In: European Federation for Information Technology in Agriculture, Food and the Environment . $463-469$.

HARTI - Hector Kobbekaduwa Agrarian Research and Training Institute. (2014). Mobitel agri price information index [online]. [Accessed on 04.05.2014]. Available at http://www.harti.gov.lk/

ITU - International Telecommunication Union. (2012). Measuring the Information Society [online]. [Accessed on 04.05.2014]. Available at http://www.itu.int/en/ITU-

D/Statistics/Documents/publications/mis2012/MIS2012_without_Annex_4.pdf

Islam, M.S., and Alawadhi, S. (2008). Sustainable rural IS implementation process for developing countries: Agriculture market information services (AMIS) in Bangladesh. pp. 127-37. In: Pettersson, J.S. (Ed.) 1st International Conference on M4D: Mobile Communication Technology for Development. Karlstad University, Sweden.

Kuutti, K. (1995). Activity Theory as a potential framework for human- computer interaction research. pp. 17-44. In: Nardi, B.A. (Ed.) Context and Consciousness: Activity Theory and Human Computer Interaction. MIT Press, London, England.

Liaw, S., Hatala, M. and Huang, H. (2010). Investigating acceptance toward mobile learning to assist individual knowledge management: Based on activity theory approach. Computers and Education, 54(2), 446-454. doi:10.1016/j.compedu.2009.08.029 
Naismith, L. and Corlett, D. (2006). Reflections on success: A retrospective of the mLearn conference series 2002-2005. pp. 1-29. In:_MLEARN 2006 Conference, 22-25 October 2006, Banff, Canada.

Nardi, B.A. (1995). Context and Consciousness: Activity Theory and Human-Computer Interaction. MIT Press, London, England.

O’Malley, C., Vavoula, G., Glew, J.P., Taylor, J., Sharples, M. and Lefrere, P. (2003). Guidelines for learning / teaching/ tutoring in a mobile environement [online]. [Accessed on 04.05.2014]. Available at MOBIlearn/UoN,UoB,OU/D4.1/1.0

Reynolds, R., Walker, K. and Speight, C. (2010). Web-based museum trails on PDAs for university-level design students: Design and evaluation. Computers \& Education, 55(3), 994 - 1003. doi:10.1016/j.compedu.2010.04.010

Uden, L., Valderas, P. and Pastor, O. (2008). An activity- theory-based model to analyse web application requirements. Information Research, 13(02) [online]. [Accessed on 16.09.2014]. Available at http://InformationR.net/ir/13-2/paper340.html from 14 May, 2008

Wang, F. and Hannafin, M.J. (2005). Design based research and technology- enhanced learning environments. Educational Technology Research and Development, 53(4), 5 - 23.

Wijeratne, M. and Silva, N.D. (2013). Mobile phone intervention for Sri Lankan mushroom producers. In 27th Annual Conference of Asian Association of Open Universities. Allama Iqbal Open University, Pakistan.

Wu, W.H., Jim Wu, Y.C., Chen, C.Y., Kao, H.Y., Lin, C.H. and Huang, S.H. (2012). Review of trends from mobile learning studies: A meta-analysis. Computers \& Education, 59(2), 817-827. doi:10.1016/j.compedu.2012.03.016

Zuga, B., Slaidins, I., Kapenieks, A. and Strazds, A. (2006). M-learning and mobile knowledge management: Similarities and differences. International Journal of Computing \& Information Sciences, 4(2), 58 - 62. 